Dwyer, Arienne. 2000. Direct and Indirect Experience in Salar. In Lars Johanson and Bo Utas, eds. Types of evidentiality in Turkic, Iranic, and neighbouring languages. Berlin: Mouton de Gruyter, pp. 45-59. Preprint.

\title{
Direct and Indirect Experience in Salar
}

\author{
Arienne Dwyer
}

\section{Introduction}

Evidentiality fundamentally concerns interaction: it is first and foremost a speaker's evaluation of the source of information about a particular event. It also concerns the other participants: the degree of their acceptance of speaker assertions, and the speaker's anticipation of this response. The source of information may be direct ('I see/hear/taste/smell/feel/do') or indirect ('I hear it reported / I infer /I discover; it happened'), may be more or less certain, or may rank subjectively higher or lower in reliability. How this evaluation is grammatically articulated is in turn affected by discourse-pragmatic factors (degree of politeness, register/genre, foregrounding, and intentionality). If the hearer challenges evidence presented, or if the speaker anticipates such a response, speakers may choose indirect/less-certain means of coding this information even though the evidence is direct/more-certain. Evidentiality is thus both a morphosyntactic issue (how and whether a language codes indirect experience), and a pragmatic one (how participants use these markers).

Here I begin with the morphosyntactic axes before considering the pragmatic ones. Salar is a language of Turkic origin with Northwest Chinese and Amdo Tibetan adstrata, spoken primarily in northern Tibet. ${ }^{1}$ As a rule, it requires speakers

\footnotetext{
${ }^{1}$.The Salars are most likely Oğuz-Turkic speakers who migrated from Transoxiana to Amdo Tibet in the $13^{\text {th }}$ century. Settling on the banks of the Yellow River in what today is Qinghai province, they intermarried with Tibetans and later Muslim Chinese, incorporating many elements of these groups into their culture and language. Today the Salars number over 90,000, but their unwritten language is rapidly giving way to the dominant languages, particularly to Chinese. On Salar origins and history, see Dwyer forthcoming 2000b; on the historical development of the Salar language, see Hahn 1988 and Dwyer 2000a.
} 
to code most utterances for (in)directness via verb suffixes, which also mark tense/aspect. Utterance-final particles contribute to the expression of participant expectations and intentionality; as such particles are only tangentially relevant for indirectivity, they will not be treated in depth here.

Direct experience is often the default experience, sometimes unmarked (though generally only so when Salar utterances include shifted Chinese structures); indirect experience is semantically and syntactically marked. Though indirectivity is a modal phenomenon, it intersects semantically with the realis-irrealis distinction (see 3.3. below). Indirectivity marking is associated with realis rather than irrealis; it can be considered to be the speaker's assessment of the degree of irrealis within realis. As one step along the road to irrealis, indirective markers keeps company with conditionals, imperatives, yes-no questions, non-implicative modal ('wanted to...') and manipulative complements (' $x$ told $y$ to..'.), and non-factive complements of cognition (' $x$ thought that...'). ${ }^{2}$

Salar rigorously distinguishes direct from indirect experience: if experience is perceived as indirect, utterances must be so marked. Predictably, indirect forms cooccur with third-person subjects, and in narratives, while direct forms are most commonly (but not exclusively) associated with first-person subjects, and in direct quotations. This reflects a cross-linguistic hierarchy of evidentiary reliability in personal deixis: speaker $>$ hearer $>$ third party (Givón 1984: 307). The correlation with personal deixis and evidential forms is so high that early studies of the language assumed that the indirect verb suffixes were third-person personal suffixes, and that the direct verb suffixes were first- and second-personal personal suffixes. Indirective markers in Salar do not, however, always mark any action by a third person as indirect, nor do they mark only unwitnessed action by the third person. Such marking is also context-sensitive.

\section{Direct/Indirect marking by suffixation}

Salar codes direct and indirect experience for anterior experience (Anterior I, II, III) and copular and existential imperfectives. ${ }^{3}$ The durative imperfective employs the existential indirective jox- $a$ in the negative.

2. Givón 1984: 286, 318. Manipulative complements are those which have an impact on self ('want, intend, try,...') or others ('order, tell, ask...').

3. Liú and Lín 1980 assert that Salar marks "definiteness"( $\approx$ indirectivity) in the durative (def. - $b \partial r$, indef. $-b a$ ) and the future (def. -Gur, indef. -Gar). My data suggests these "indefinite" forms are semantically unrelated to indirectivity and are simply phonologically variant forms of $-B A(r)$ and Gur Gar, respectively. 
Table I. Salar verb suffixes/clitics with indirective oppositions

\begin{tabular}{|c|c|c|c|c|}
\hline & $\begin{array}{r}\text { Direct } \\
\text { affirmative }\end{array}$ & negative & affirmative & $\begin{array}{l}\text { direct } \\
\text { negative }\end{array}$ \\
\hline Anterior I: preterite & $-d \xi i$ & $-m A-d z i$ & $-m i \check{s}$ & $-m A-m i \check{s}$ \\
\hline Anterior II: terminal & $-G A n$ & $-m A-G A n$ & $-m i \check{s}$ & $-m A-m i \check{s}$ \\
\hline Anterior III: experiential & -GAn var & -GAn jox-tïr & -GAn var-a & $-G A n$ jox- $a$ \\
\hline Copula & (i)-dïr & emes, emes-tïr & (ir)-a & emes- $a$ \\
\hline Existential & var & jox, jox-tïr & var-a & jox-a \\
\hline Imperfective I: pres.-dur. & $-B a(r)$ & jox-tïr & $-B a(r)$ & jox- $a$ \\
\hline
\end{tabular}

$(\mathrm{G}=\breve{\mathrm{g}} / \mathrm{s} / \mathrm{G} / \mathrm{g} ; \mathrm{B}=\mathrm{b} / \mathrm{p} ; \mathrm{A}=\mathrm{a} / \mathrm{a})$

The scant material available on "premodern Salar" present 100-200 years ago: direct $-D i$ and -GAn vs. indirect -miš; direct (er)dir (>(i)dir) and ermes vs. indirect emes ar $i$. (No affirmative indirect form is attested in these three texts, but one can extrapolate $\operatorname{ar}(i)$.)

\subsection{Anterior}

\subsubsection{Anteriors I, II dzi : -mǐs; -GAn : -mǐ̌}

Salar preserves the Old Turkic indirectivity distinctions for anterior events: events are marked as directly experienced with - dzi $(<$ Turkic $-D I)$ and Middle Turkic -GAn, and as indirectly-experienced with $-m i \check{s}$ (< Turkic -miš). In historical narratives, where the events related are [+realis] for the speaker, -ḑi and-GAn mark assertions within the speaker's direct experience, while -miš marks those events experienced indirectly by the speaker, and are thus associated with first-person subjects, as in the following example of an elderly man relating his wartime experiences:

(1) piser kučara bardz̧i. kučara barsa, u gasolin digän maxuo šäglär anda Gašmiš tə, ular da kučara gelmiš.

$[152.31,33]^{5}$

'We went to Kucha. When we went to Kucha, he hid the gasoline there around Maxuo county, and they also came to Kucha.'

4. To date, only three text fragments in "premodern Salar" have been studied (Tenishev 1976, Hán 1988, Hán 1989). This material must be treated with extreme caution, since the texts themselves have not been made public (except in Tenishev 1976), and background information has not been provided; it is as yet unclear if these texts are in fact related to modern Salar.

5. The Salar data in this paper are from my field research in China during 1991-1993, unless otherwise noted. Numbers in brackets refer to text and utterance number(s). 
However, in fictional narratives, events are assumed to be [-realis] and completely outside of the realm of the speaker's experience; predictably, the default markers are indirective -miš and $a$, as in the following typical story opening:

(2) nenosur var $\underline{\text { a. }}$ bowusur varar a. ... indzi awučuxniği abast vursen adziuniği helli bidza očile apparmiš.

$[56.1,2,6]$

'There was an old woman and an old man. (...) So the boy's father borrowed some of Uncle Vursen's money.'

Yet the consistent use of indirectives in such fictional narratives is interrupted by dialogue, which is marked by directives:

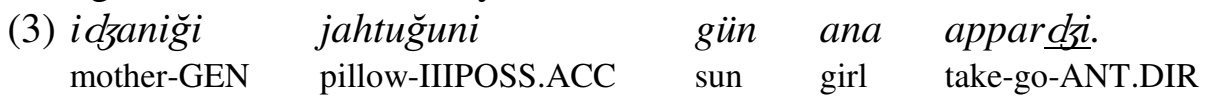

'The sun maidens took your mother's pillow'

The presence of Old Turkic perfect/evidential -miš as an indirective marker in Salar is a conservative feature shared with Oghuz Turkic. It does not occur in Salar's geographically closest Turkic neighbor, Sarïgh Yoghur; although in modern standard Uyghur evidential -miš has largely supplanted by $i k a ̈ n,{ }^{6}$ in many southern Uyghur dialects -miš is still used as an evidential.

\subsubsection{Anterior III: Composed past/Experiential}

The indirective opposition for the existential (var : var-a) forms the basis for the Salar experiential past: direct -GAn var (neg. -GAn joxtïr) < Turkic experiential past $-G A n+$ existential bar; indirect -GAn vara (neg. $-G A n$ joxa) $<-G A n+$ bar + indirective clitic $a$ (see 2.2 below).

(4) a. men bedzina varğan var

b. $u$ bedzina varğan var a

c. $u$ bedzina varğan joxtır/joxa
'I have been to Beijing'

'S/he has been to Beijing'

'S/he hasn't been to Beijing'

(direct/indirect)

When the reportative is emphasized, an embedded construction is used, with indirective marking on the matrix verb (as in 5a) or on the main verb (as in 5b). The western dialect of Salar, spoken in a largely Uyghur/Qazaq-Turkic area, appears to favor such complex constructions over -GAn var/vara compositae:

6. The supplanting of the Old Turkic perfective/evidential -mif by Chagatay ikän has resulted in a narrowed semantic scope of the former as a dubitative marker. 
(5)

$\begin{array}{llllll}\text { men } & \text { ani } & \text { bedzina } & \text { varmiš } & \text { de } & \text { ištedzi } \\ \text { I } & \text { (s)he-ACC } & \text { Beijing-DAT } & \text { go-ANT.IND } & \text { CNJR } & \text { hear-ANT.DIR }\end{array}$

'I heard s/he went to Beijing'

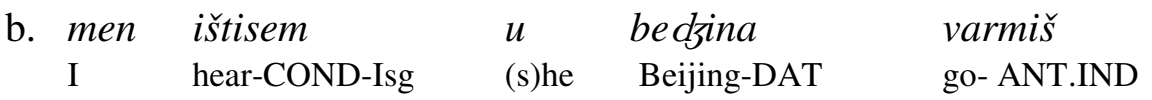

'I hear/heard s/he went to Beijing'

\subsection{Imperfective}

The three imperfectives relevant to indirective oppositions are copular and existential constructions, and the present-durative. All are based on the opposition $\{-\varnothing /-D I r$ : $-a\}$ : zero marking or $-D I r$ for the directive, and the clitic $a$ in the indirective.

\subsubsection{Copular and existential constructions}

In direct declaratives, the explicit marking of the copula with (i)dir (< Turkic är-dur) is usual (unlike Turkic languages such as modern Uyghur, in which zero marking in copular constructions is neutral, and the use of dur is emphatic). In connected speech in Salar, however, explicit copular marking in the declarative is not obligatory; this may be related to the shift of Chinese and Tibetan structures into Salar (see 3.3 below).

$\begin{array}{lllll}\text { (6) } \begin{array}{lll}u \\ \text { (s)he }\end{array} & \text { miniği } & \text { tiut } & \text { šxuxum } & \text { dır } \\ & & \text { Tibetan } & \text { friend-I.POSS } & \text { be-DIR }\end{array}$

'She/He's my Tibetan friend.'

[Hán 1983]

$$
\text { idvr i 'Is that so?' }
$$

Indirect declaratives are marked with the clitic $a$ :

(8) asmanda neččä jultus vara ? 'How many stars are in the sky?' [Hán 1983]

(9) ren xe ren bir ira bele. 'People are all the same.'

(10) ajso, sen futan ira mu? 'Ayso, are you well off?' 
The origin of the indirective clitic $a$ can only be hypothesized. Given that the Salar verb paradigm contains many Chaghatay elements, one can consider the that Salar $a$ might be the result of severe phonological erosion of the Chaghatay indirective är-

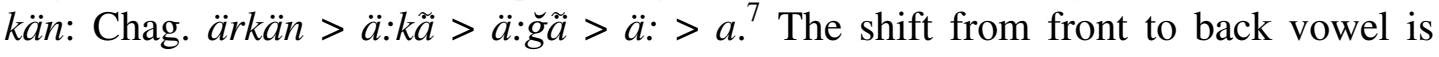
obviously problematic, until we consider that Salar has borrowed the back-vocalic Chinese exclamatory particle $a$, which also occurs utterance-finally. The Salar indirective marker may have become back by analogy with the exclamatory particle. ${ }^{8}$

Sarïgh Yoghur, Salar's geographically closest Turkic neighbor, has a superficially similar form er (< likely Turkic är 'be'), but it is semantically and structurally different from Salar $a$; Sarïgh Yoghur er is an emphatic ('certainly'), is associated with certain verb forms (mostly the future-GəS ), and can be negated with the Turkic negative infix -m(A)-, as in -Gos-mer):

$$
\begin{array}{ll}
\text { a. duhtGəŞ- } \underline{\text { er }} & \text { 'will certainly do [it]' } \\
\text { b. duhtGəŞ- } \underline{\text { mer }} & \text { 'will certainly not do [it]' }
\end{array}
$$

serən namərdzal kun sen saGəs satda čüğe gelej dro ( gelğəs dro), buğən neğe gelmeğgen er?

'Seren Namerjal comes every day to the district at eight, why hasn't he come today?'

Although it is likely that both Salar $a$ and Sarïgh Yoghur er derive from the Middle Turkic copula $\ddot{a} r$, they have been grammaticalized to such different functions that their only commonality is that they both indicate markedness.

Salar $a$ has become specialized as an indirective marker; in the following, a speaker relates the legend of the Salars' settlement in Amdo Tibet, using indirective forms throughout to indicate that it is indeed legend:

7. All but the last stage are typical Salar weakening processes: preconsonantal $r>\varnothing$ (cf. qut $<$ qurt 'worm, bug'); intervocalic $\mathrm{k}>\breve{\mathrm{g}}>\varnothing$ (cf. genitive $-n i \sim-n i \breve{g} i<-\mathrm{ni}+\mathrm{ki}$ ); final nasal deletion, nasality spreads onto previous vowel $\mathrm{Vn}>\mathrm{V}$ (cf. sequential -djinen $\sim$-dzine).

8. Another possible origin of modern Salar indirective $a$ is the Written Mongolian copular auxiliary a-. (Liú and Lín 1980: 26). Although the Salars had extensive contact with Mongolian speakers during the $13-16^{\text {th }}$ centuries, morphosyntactic loan features from Mongolian are otherwise entirely absent in modern Salar, rendering this hypothesis unlikely. Salar's geographically closest modern Mongolic neighbor, Baonan, has, however, direct/indirect distinctions for anterior, imperfective, and existential constructions, based (at least for the latter two) on an $i: a$ distinction, e.g. tərə malGə məngə $m b i / m b a$ 'That hat is mine (direct/indirect).' (In Salar: vu zorax miniği dir/ira 'id.') (Liú and Lín 1980). As tempting as it might be to derive Salar $a$ from the Baonan indirective $a$, there is no parallel evidence of other Mongolic structures or morphemes elsewhere in Salar grammar to warrant such a claim. 


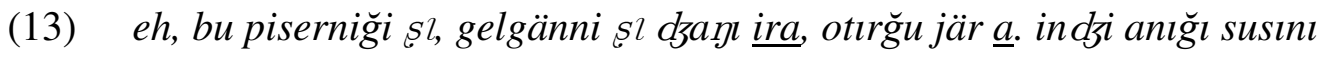
čänpin a. piser dərzı̆ğa vursa, andă̆ı su mundağı su bir zänzını dərzı̆ğa vursa, ăğtllğg bir $\underline{a}$.

'Yeah, [in] our coming [here], all around were places to settle. And so the water was the real thing. When we weighed it, weighed a bowl of water from there and one of water from here, they were the same.'

\subsubsection{Imperfective I: present/durative}

In the affirmative, the present-durative (marked by $-B a(r)$ ) is irrelevant to indirectivity. Its negated forms, however, have converged with negative existentials, and therefore display the $\{-D I r:-a\}$ opposition: direct $=\mathrm{V}+$ joxdlr , indirect $=\mathrm{V}+$ joxa.
a. $m e$
$\begin{array}{ll}\text { čuxur } & \text { pitibar } \\ \text { now } & \text { write-DUR }\end{array}$
'I am writing now'
b. men piti
jiti joxtlr
'I am not writing'
c. $u$
piti joxa
'S/he is not writing'

\section{Discourse-pragmatic factors}

Speakers choose socially meaningful speech styles based on the situation and its participants. The social and pragmatic intentions of the participants and the type of communication mode ("genre") to a large extent determine the choice of indirective markers. These factors may result in indirective marking that is at odds with some of above examples of "textbook indirectivity" (i.e. the information is reported/ inferred/discovered/uncertain). Social factors such as deference, pragmatic factors such as foregrounding, and structural factors such as the required collocations associated with certain genres can all contribute to the choice of indirective markers.

\subsection{Intentionality}

The intentions of the participants vis-à-vis the conversational topic and each other can result in the choice of indirectives to mark what is clearly direct experience. In 
one conversation, a ninety-year-old woman is being interviewed by a much younger Salar man she has not met previously, who asks her about veiling practices long ago:

$\begin{array}{lllll}\text { a. } & \text { seler } & \text { kiči } & \text { voğanda } & \text { getu daxənbar } \\ \text { you-PL } & \text { small } & \text { when } & \text { head.covering wear-IMP } & \text { INT }\end{array}$

'When you were young, did you cover your heads?'

$\begin{array}{lr}\text { b. } \begin{array}{l}\text { daxən } \\ \text { wear }\end{array} \text { not-INDIR } & \text { 'No, we didn't.' }\end{array}$

Although it is clearly part of her direct experience, the interviewee has marked her response as indirect in order to distance herself from that event, likely because most Salar women regard it as shameful not to cover one's head.

The many uses of indirectives to convey participant intentionality is a topic beyond the scope of this paper. Aside from marking the speaker's subjective distance from the topic, indirectives are also used to convey elements of the participant relationship, e.g. politeness or deference, a topic touched on in 3.2.1. and 3.2.2.

\subsection{Genre}

Salar oral texts can be categorized on thematic and structural grounds into the following major text types: conversations, narratives (historical narrative, narrative descriptions, and fictional narratives), speeches, songs, and sayings (proverbs and riddles). Each genre reflects certain tendencies with regard to indirectivity; of these, conversations, speeches, and narratives reveal most clearly how speakers make context-sensitive choices in marking an event as (in)direct.

In speech acts with highly codified stylistic structures (greetings and leavetakings, prayers, and wedding speeches), the speaker has less or even no free choice in indirectivity marking. He or she may be bound to specific collocations (Oholda... 'Once upon a time...', ... siuz bu $d a$ '....and so be it.'). In these kinds of speech acts, the speaker is more detached from active participation in the discourse process. The less codified the speech act (e.g. in conversations or even fairy tales), the more involved the speaker can be in marking indirectivity.

\subsubsection{Conversations}

The presence of multiple active participants means that intentionality comes to the fore. Conversations have the highest degree of flexibility in combining verbal with sentential markers; the latter are employed extensively. In addition to the verbal 
markers of indirectivity, certain discourse particles optionally serve to reinforce the (in)directness of an utterance. The degree of certainty of assertion is very important in dialogic discourse.

Examples (16)-(18) are excerpts from a conversation between a father, his adult son, and his son's friend. In (16), the friend asserts his own age indirectly (with a comparative construction, and a confirmative particle $b a$ 'must be...'), and the father deduces his age. Both the assertion and conclusion drawn represent information from an indirect source, and the degree of certainty is low, hence the indirective marking of the first two utterances. However, the father's conclusion is wrong; the son's friend corrects him using an unmarked directive, for he is certain in his knowledge, as it refers to himself:

(16) Friend: men jusuğa vaxsa, bir dzadax ira ba. 'I'm a year older than Yusuf' Father: sislji $\underline{a}$. 'Forty-one (I take it).'



Unlike in narrative quotations (cf. (3) above), in conversations the speaker apparently has the option of coding a quoted assertion as an indirective or directive. Compare the first and fourth utterances in (17):

Friend: seniği abay seni slşl volmiš debar. pini tay siş̨ ira mu?

'Your dad said you're forty. Are you really forty?'

Son: $\tilde{a}:$ ?

'Huh?'

Father: $u$ säns șlsı volbar debar.

'He says you're thirty-four.'

Friend:pin sişl ira mu?

'Are you really forty?'

Son: e uvar $\underline{a}$, sansl $\underline{a}$.

'Eh right; I'm thirty-four.'

[53.102-107]

Except for the father's statement above, the dialogue is consistently indirect, reflecting the uncertainty of the information, or a sudden realization ('Eh right...').

Direct forms are used in the negative; for the affirmative answer, the speaker uses the indirective -miš, even though he is certain of the information:

Father: seniği aba be, vučay volğanda liuş girmadz̧i ba?

'Your father, he wasn't yet sixty-nine when he passed away, was he?'

Friend: liuşlsl volmiš. $\quad$ 'He was sixty-four.' [53.119-121]

Indirectivity marking in conversations is thus very topic- and speaker-dependent. Those conversations which involve the deferential negotiation of information (such as the above) strongly favor indirect forms. Where the certainty or source of 
information is not being negotiated and the participants' intentions are focussed elsewhere, direct forms are more common. The confirmative particle $b a$, indicating the speaker's expectation of listener agreement, co-occurs with both direct and indirect markers; with the latter (as in 16), it nudges the assertion in the direction of directivity and thus partially neutralizes the indirective marking.

\subsubsection{Speeches}

Formal speeches such as those at weddings are among the most highly codified speech acts in Salar. Wedding speeches are presented largely in a question-andanswer format; when directivity is marked at all (questions are often conditionals, and answers often imperatives), direct forms are overwhelmingly favored. These timeless truths constitute information of unquestionable certainty, even if the source of information is nebulous, and even if the assertion is counterfactual:

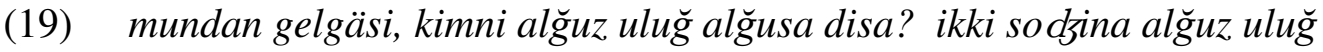
alğusa dir $i$. nanniği jolina disa? asmanda bulut joxmasa, rahmät joxtur dir $i$. ziminda sodzi joxmasa, urux joxtur dir $i$.

'Continuing on, who [else] is respected? It is the matchmakers. In which way are they respected? Without clouds in the sky, there would be no rain (lit. 'favor'). Without matchmakers on earth, there would be no family.'

The indirective $a(r)$ intrudes, rarely, into an otherwise directive discourse, generally under two circumstances. The first is in utterances with second-person referents, out of deference; note how second-person sän is associated with indirective ar $i$ while first person miniğ $i$ is associated with directive adır $i$ :

ullı etse, qulax sän Gonaxniği ar $\underline{i}$. lombä șl miniği ojčiniği adır $i$.

'If you accord them respect, the ears are those of you guests; the gifts are those of us hosts.'

The second structure in which indirectives appear is in a question-answer; an indirective question requires an answer with parallel marking, on stylistic grounds:

şıba tsiän ma mexeluğu išinde, džlgue dzig șl nay ar $i$ ? ejčo adam ar $i$.

'Of the 18,000 living beings, which is the most precious? It is man.' [1.64-65] 
The emphatic particle $i$, which indicates the speaker expects the proposition to be factive, neutralizes the indirective sense of ar. Pragmatically, $i$ serves in both (20) and (21) to reinforce the authority, certainty, and factivity of the information presented. The entire speech never strays from direct discourse; such particles therefore contribute to the overall coherence of a given speech act.

\subsubsection{Narratives}

These are bounded events strongly associated with past tense and indirect forms. Narratives may be punctuated by direct forms (-GAn, -Ar) in sudden change of state. These interruptions in the narrative sequence tend to be marked unbounded experiences (hence the experiential $-G A n$ ). The evidential system in narratives often simplified. Unlike in other genres such as conversations, the indirect forms are default. The predictable alternations between direct and indirect forms is largely related to foregrounding and backgrounding.

\subsection{Foregrounding/backgrounding}

Hopper and Thompson (1980) showed a probabalistic correlation between realis and foreground, and irrealis and background. Salar discourse data suggests that this correlation can be extended to indirectivity (demonstrating the semantic link between irrealis and indirectivity): foregrounded information correlates with directivity (and often unmarked); backgrounded information correlates with marked indirectives, at least in narrative discourse.

In the following historical narrative presented overwhelmingly with indirect forms, direct forms appear occasionally to foreground currently relevant information:

\section{su fala čix gelčänä asnı jigua tannamiš. wu jyä išinda oraxni orğur orğur} boğdajni orğur. wu jig șldziända, jigua su taynadzinän joğan etmiš $a-a s$.

'Water came up out of the ground and flowed all over the fields. By May [we] would be scything and scything (lit., 'will scythe'), scything the wheat. At that time, water flowed everywhere and they grew well ('big'), the fields.' [5.83-85]

Foregrounded information is often completely unmarked. ${ }^{9}$ In Salar, the Chinese copula shi [sı] has been grammaticalized as a topic-marker. When such utterances are

9. Although unmarked foregrounded information is typical of creole languages, Salar cannot be considered to be a creole, for it is not a gramatically reduced or pragmatically/socially restricted language variety. Salar is a Turkic language with massive Chinese and Tibetan adstrata at all levels of 
non-copular in Salar, one inevitably finds a directive verb suffix, even in a historical narrative where one would expect indirectives:

$$
\text { piserniği ardzina jiraxni gelgänniği șl slşl gə šejxej gelgän. }
$$

'The ones who came from afar after us were (lit., 'came') the forty learned men'

When utterances topicalized with sl have a copular sense in Salar, the expected utterance-final Turkic copula (idir/ira) is almost always absent: sl appears to have retained its copular sense from Chinese:

$$
\text { u jedzisi șl axman xə Garamanniği oğll. }
$$

'Those seven were the sons of Aqman and Qaraman.'

As a non-topicalized utterance, the above would likely be rendered as: ular axman xə Garamanniği jedzi oğlı idır/ira. 'They were the seven sons of Aqman and Qaraman.' Yet even when a Turkic foregrounding topicalizer is used, the copula is also absent. In the first utterance below, sänbai dzia 'thirty households' is marked off as a topic by dedzinän 'saying'; the second utterance uses the Chinese topicalizer sli; neither have the expected Turkic copula utterance-finally:

sänbai dzia dedzinän, beligi ji goy [Ø].

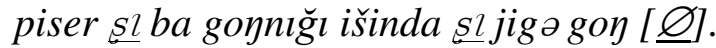

'As for the thirty households, they constitute one gong.

Ours is one of the eight gong.'

The necessity for marking indirectivity in Salar has been rendered irrelevant by the foregrounding of the utterance through topicalization.

\subsection{Gender of participants}

The frequency of direct forms may be correlated with gender. Female speakers of Salar tend to use more indirect forms. Even direct quotations embedded in narratives related by females are often entirely in -mišs. Narratives related by males tend to favor

language. What Salar has in common with many creole languages are sociohistorical features (e.g. the displacement of the ancestral Salar population from their Central Asian homeland, and the current low prestige of the language). 
the directive -GAn form. This could also be due to the choice and perception of subject matter: men often choose to talk about history and legends, which they may have perceived as relatively factual, direct, and based on reliable information. It is mostly women who tell tales of fantasy, which they in turn may have perceived as so far beyond immediate experience that they have to be couched in indirectives. But when men tell epics and fairy tales, and when women relate their local history, the gender correlation appears to hold. A broader textual survey is clearly needed.

\section{Summary}

Ultimately direct/indirect marking is both a syntactic and a pragmatic constraint. Indirectivity markers are often used as expected for reported/inferred/new information, and are thus often associated with third-person referents in discourse. However, utterances referring to the first person may be marked as indirect to indicate speaker distance from the topic or other speaker intentions; those referring to the second person may be indirect out of politeness or deference. The relationship between the speaker, the topic, and other participants thus mediates the choice of indirectivity marking. The genre of speech act itself partially determines the flexibility a speaker has in such marking. Utterance-final particles play a tangential but important role in maintaining overall textual coherence by partially neutralizing the sense of those indirectivity markers required by morphosyntax but that are otherwise out of place. 


\section{References}

Chén Zòngzhèn-Léi Xuănchūn

1985 Xībù Yùgùyŭ jiănzhì [A concise grammar of Western Yugu

[= Sarïgh Yoghur]]. Bĕijīng: Mínzú.

Dwyer, Arienne M.

1998 The Turkic strata of Salar: An Oghuz in Chagatay clothes?

Turkic Languages 2.1: 49-83.

forthcoming 2004a Salar: a study in Inner Asian areal contact

processes, Part I: Phonology. Wiesbaden: Otto Harrassowitz.

$2000 \quad$ Historische Fragen zur Ethnogenese der Salaren. In P. Kappert und

K. Buğday, eds. 4. Deutsche Turkologen-Konferenz. Hamburg.

Givón, Talmy

1984 Syntax: A Functional-Typological Introduction. Vol. 1.

Amsterdam: Benjamins.

Hahn, Reinhard

1988 Notes on the origin and development of the Salar language. Acta Orientalia Academiae Scientiarum Hung. XLII (2-3): 235-275.

Hán Jiànyè

1983 "Sālāyŭ jùzı̄ fenlèi" [A Classification of Salar Sentences].

Qīnghăi mínzú xuéyuàn xuébào 1: 68-76.

1988 “Tăn Tùérkèwén” [On Written Turki]. Unpublished MS.

1989 “Cóng wénxiàn zīliào kàn Sālāyŭ de fāzhăn biànxuà” [Observing changes in the development of Salar from documentary material]. Xībĕi mínzú yánjiū 2: 173-182.

Hopper, Paul J.-Sandra A. Thompson

1980 "Transitivity in Grammar and Discourse". Language 56: 251299.

Líu Zhàoxiōng-Lín Liányún

1980 "Bāoānyŭ hé Sālāyŭlĭ de quèdìng yŭ fēiquèdìng yŭqì" [Definite and indefinite mood in Baonan and Salar]. Mínzú yŭwén 1: 23-28.

Tenishev, E. R.

1976 "Otryvok iz Istorii Salarov" [A Fragment from The History of the Salars]. Ural-Altaisches Jahrbuch 48: 237-248.

Trippner, Josef.

1964 "Die Salaren, ihre Glaubensstreitigkeiten und ihr Aufstand 1781" Central Asiatic Journal 9: 4. 241-276. 